Vol. 6, No. 1, Februari 2018

Efektifitas Media Film dengan Leaflet dalam Peningkatan Pengetahuan Ibu Rumah Tangga tentang DBD di Desa Pekalongan Kabupaten Pati

Dobby Raka Sandi Susetya, Ervi Rachma Dewi

Menggali Kefektifan Peran Ibu dengan Anak Usia Pra Sekolah selama Berada di Rutan Kudus Aliani Nailil Izzah, Sri Hindriyastuti

Perbedaan Kadar BOD Limbah Cair Sebelum dan Setelah melewati Biofilter Tanaman Cattail (Typha angustifolia) Pujo Prasetyo, David Laksamana Caesar

Gambaran Kepatuhan Ibu dalam Pelaksanaan Imunisasi DPT/Hb Lengkap di Puskesmas Punggelan 2 Kabupaten Banjarnegara Lia Aria Ratmawati, Rosiyani Hermawati

Hubungan Riwayat Kontak Penderita dengan Kejadian Tuberkulosis Paru Anak Usia 1-14 Tahun di Balai Kesehatan Masyarakat Pati Risna Endah Budiati, Noor Khoirina

Hubungan Dukungan Keluarga dengan Pemberian ASI Eksklusif pada Bayi di Desa Jambean Kidul Kecamatan Margorejo Nanik Royaningsih, Sri Wahyuningsih

Jumlah Kehamilan dan Kematian Ibu Berdasarkan Letak Wilayah Ketinggian di Kabupaten Pekalongan Rokhani, Indri Astuti Purwanti 


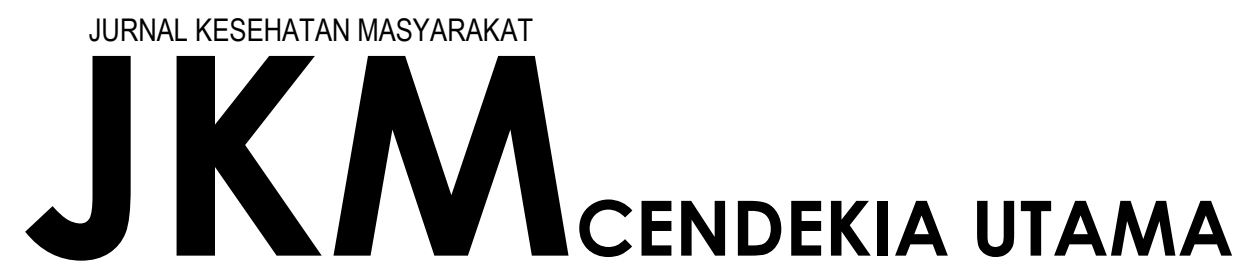


Vol. 6 No. 1

P-ISSN 2338-6347

Februari, 2018

E-ISSN 2580-992X

\section{$\mathbf{J} \mathbf{M}_{\text {cendekia utama }}$}

\section{Editor in Chief}

Eko Prasetyo, S.KM., M.Kes. STIKES Cendekia Utama Kudus, Indonesia

\section{Editorial Board}

Sri Wahyuningsih, S.KM., M.Gizi., STIKES Cendekia Utama Kudus, Indonesia Risna Endah Budiati, S.KM., M.Kes., (Epid), STIKES Cendekia Utama Kudus, Indonesia

Ervi Rachma Dewi, S.KM., M.Kes., STIKES Cendekia Utama Kudus, Indonesia David Laksamana Caesar, S.KM., M.Kes., STIKES Cendekia Utama Kudus, Indonesia

\section{Reviewer}

Sigit Ari Saputro, S.KM., M.Kes., Universitas Airlangga, Surabaya, Indonesia dr. Mahalul Azam, M.Kes., Universitas Negeri Semarang, Indonesia

Eti Rimawati, S.KM., M.Kes., Universitas Dian Nuswantoro, Semarang, Indonesia Didik Sumanto, S.KM., M.Kes. (Epid), Universitas Muhammadiyah Semarang, Indonesia

\section{English Language Editor}

Arina Hafadhotul Husna, M.Pd., STIKES Cendekia Utama Kudus, Indonesia

\section{IT Support}

Susilo Restu Wahyuno, S.Kom, STIKES Cendekia Utama Kudus, Indonesia

JKM (Jurnal Kesehatan Masyarakat) Cendekia Utama merupakan jurnal ilmiah dalam bidang kesehatan masyarakat yang diterbitkan oleh Program

Studi S1 IImu Kesehatan Masyarakat STIKES Cendekia Utama Kudus secara berkala dua kali dalam satu tahun 


\section{KATA PENGANTAR}

Salam MIRACLE,

Puji syukur selalu senantiasa kita panjatkan kehadirat Allah SWT yang telah melimpahkan Rahmah Hidayah dan Ilmu-Nya, sehingga JKM (Jurnal Kesehatan Masyarakat) Cendekia Utama Kudus Vol. 6, No. 1 dapat kembali terbit pada bulan Februari 2018 ini. Pada kesempatan yang baik ini kami menyampaikan ucapan terima kasih dan apresiasi yang setinggi-tingginya kepada bapak ibu mitra bestari, para peneliti, tim redaksi, dan semua pihak yang telah mendukung atas terbitnya JKM Cendekia Utama Vol. 6, No. 1 ini.

JKM Cendekia Utama merupakan jurnal ilmiah di bidang kesehatan masyarakat yang diterbitkan secara berkala 2 (dua) kali dalam setahun oleh Program Studi S1 Ilmu Kesehatan Masyarakat STIKES Cendekia Utama Kudus. JKM Cendekia Utama mempublikasikan informasi ilmiah hasil penelitian dengan kajian: Epidemiologi, Kesehatan Lingkungan, Keselamatan dan Kesehatan Kerja (K3), Promosi Kesehatan, Biostatistik dan Kependudukan, Administrasi Kebijakan Kesehatan (AKK), Manajemen Kesehatan, Gizi Masyarakat, Kesehatan Ibu dan Anak (KIA), Kesehatan Reproduksi, dan kajian-kajian pengembangan ilmu di bidang kesehatan masyarakat.

JKM Cendekia Utama kembali mengundang berbagai ilmuan dari berbagai lembaga pendidikan tinggi maupun peneliti untuk memberikan sumbangan ilmiahnya dalam bentuk artikel ilmiah dari hasil penelitian, laporan/studi kasus, kajian/tinjauan pustaka di bidang kesehatan masyarakat dalam rangka mengatasi permasalahan kesehatan masyarakat yang semakin kompleks.

Redaksi sangat mengharapkan masukan-masukan dari para pembaca dan professional bidang kesehatan masyarakat untuk peningkatan kualitas jurnal dan berharap semoga artikel-artikelyang termuat dalam JKM Cendekia Utama bermanfaat dalam pengembangan ilmu di bidang kesehatan masyarakat.

\section{Pimpinan Redaksi}

Eko Prasetyo, S.KM., M.Kes. 


\section{DAFTAR ISI}

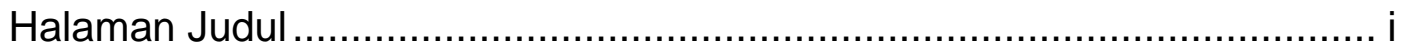

Susunan Dewan Redaksi..................................................................

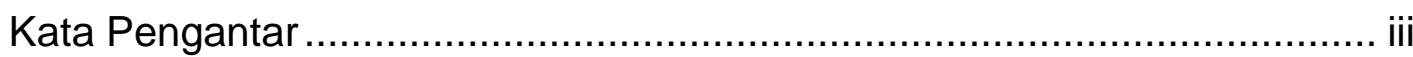

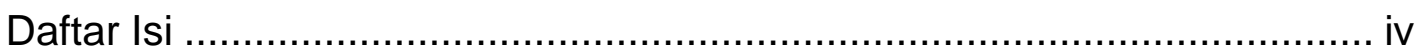

Efektifitas Media Film dengan Leaflet dalam Peningkatan Pengetahuan Ibu Rumah Tangga tentang DBD di Desa Pekalongan Kabupaten Pati Dobby Raka Sandi Susetya, Ervi Rachma Dewi........................................ 1

Menggali Kefektifan Peran Ibu dengan Anak Usia Pra Sekolah selama Berada di Rutan Kudus

Aliani Nailil Izzah, Sri Hindriyastuti........................................................ 16

Perbedaan Kadar BOD Limbah Cair Sebelum dan Setelah melewati Biofilter Tanaman Cattail (Typha angustifolia)

Pujo Prasetyo, David Laksamana Caesar

Gambaran Kepatuhan Ibu dalam Pelaksanaan Imunisasi DPT/Hb Lengkap di Puskesmas Punggelan 2 Kabupaten Banjarnegara

Hubungan Riwayat Kontak Penderita dengan Kejadian Tuberkulosis Paru Anak Usia 1-14 Tahun di Balai Kesehatan Masyarakat Pati Risna Endah Budiati, Noor Khoirina.

Hubungan Dukungan Keluarga dengan Pemberian ASI Eksklusif pada Bayi di Desa Jambean Kidul Kecamatan Margorejo

Jumlah Kehamilan dan Kematian Ibu Berdasarkan Letak Wilayah Ketinggian di Kabupaten Pekalongan

Rokhani, Indri Astuti Purwanti 62

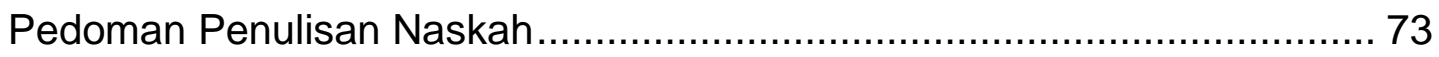

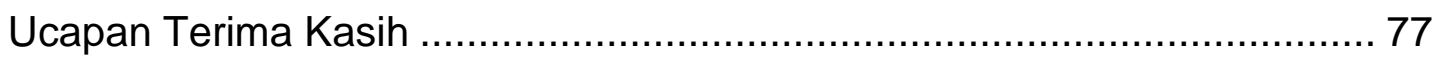




\title{
HUBUNGAN RIWAYAT KONTAK PENDERITA DENGAN KEJADIAN TUBERKULOSIS PARU ANAK USIA 1-14 TAHUN DI BALAI KESEHATAN MASYARAKAT PATI
}

\author{
Risna Endah Budiati ${ }^{1}$, Noor Khoirina ${ }^{2}$ \\ 1,2Program Studi Ilmu Kesehatan Masyarkat STIKES Cendekia Utama Kudus \\ Jl. Lingkar Raya Kudus-Pati KM. 5 Jepang Kecamatan Mejobo Kabupaten Kudus \\ Telp. (0291) 4248655, 4248656 Fax. (0291) 4248657 \\ e-mail : risna.eb@gmail.com; noorkhoirina13@gmail.com
}

\begin{abstract}
ABSTRAK
Tuberkulosis (TB) yang dulunya sering disebut TBC disebabkan oleh bakteri Mycobacterium tuberculosis yang paling sering mempengaruhi paru-paru. Data yang diperoleh dari Balai Kesehatan Masyarakat Pati menyebutkan bahwa pada tahun 2016 jumlah kasus TB paru anak usia 1-14 tahun sebanyak 26 anak. Tujuan dari penelitian ini adalah untuk menganalisis hubungan riwayat kontak penderita dengan kejadian Tuberkulosis Paru anak usia 1-14 tahun di Balkesmas Pati.Penelitian ini menggunakan penelitian analitik observasional dengan pendekatan case control. Besar sampel yang diambil sejumlah 52 yang terdiri dari 26 kasus dan 26 kontrol. Instrumen yang digunakan dalam penelitian ini adalah kuesioner. Korelasi chi-square digunakan untuk mencari hubungan dan menguji hipotesis antar kedua variabel. Berdasarkan uji statistik menunjukkan bahwa ada hubungan antara riwayat kontak penderita dengan kejadian tuberkulosis paru anak usia 1-14 tahun ( $p$ value $=0,007$ dan $r$ hitung $=12,243$ ). Kesimpulan penelitian ini adalah ada hubungan antara riwayat kontak penderita dengan kejadian tuberkulosis paru anak usia 1-14 tahun.
\end{abstract}

Kata Kunci : riwayat kontak, TB paru, anak

\begin{abstract}
Tuberculosis (TB) formerly known as TBC is caused by the Mycobacterium tuberculosis that most often affects the lungs. The secondary data from Community Health Center Pati showed that in 2008 the amount of children TBC is 26 cases. The purpose of this research is to analyze the relationship history of contact with the incidence of pulmonary tuberculosis children aged 1-14 years in Balkesmas Pati. The design of this research is observational analitycal study with case control approach. Sample from this research was 52 patients divided into 26 cases and 26 controls. Instrument using in this reseach was quetioner. The chisquare correlation is used to find the relationship and test the hypothesis between the two variables. Through statistic test showed that there is a relationship between history of contact with the incidence of pulmonary tuberculosis children aged 1-14 years in Balkesmas Pati. The conclution of this research is there is a relationship between history of contact with the incidence of pulmonary tuberculosis children aged 1-14 years in Balkesmas Pati.
\end{abstract}

Keyword : Contact history, TB disease, children 


\section{PENDAHULUAN}

Tuberkulosis (TB) yang dulunya sering disebut TBC disebabkan oleh bakteri Mycobacterium tuberculosis yang paling sering mempengaruhi paru-paru.[1] Dalam kasus tuberkulosis ada tuberkulosis pada orang dewasa dan tuberkulosis pada anak. Tuberkulosis pada anak merupakan masalah khusus yang berbeda dengan tuberkulosis pada orang dewasa. Data Profil Kesehatan Kabupaten Pati angka kasus TB paru anak tahun 2015 sebesar 33 kasus (5\%), dan tahun 2016 sebesar 37 kasus (6\%). [2] Sedangkan untuk angka kasus TB paru anak usia 1-14 tahun yang ditemukan di Balkesmas Pati pada tahun 2014 ada 68 kasus, tahun 2015 ada 86 kasus, tahun 2016 ada 88 kasus. Tetapi untuk angka kasus TB paru anak usia 1-14 tahun yang diobati di Balkesmas Pati, pada tahun 2016 - Februari 2017 Balkesmas mengobati 26 kasus TB paru anak usia 0-14 tahun yang lebih tinggi dibandingkan tahun 2015 dengan 24 kasus terobati. Berdasarkan data dari tahun 2014 sampai bulan Februari 2017 diperkirakan bahwa kasus TB anak yang ditemukan dan diobati pada bulan-bulan berikutnya akan mengalami peningkatan, hal ini bisa dilihat dari angka kasus TB dewasa yang juga mengalami peningkatan. Target kasus TB anak dari Balkesmas adalah 0 kasus, berarti untuk TB paru anak usia 0-14 tahun masih jauh dari target. [3]

Faktor risiko utama penyebab tuberkulosis paru pada anak adalah karena adanya riwayat kontak dengan penderita TB paru, hal ini dikarenakan daya tahan tubuh anak yang masih lemah sehingga bakteri bisa dengan mudah masuk ke dalam tubuh. Dalam pengertian kontak diartikan dengan tinggal di rumah yang sama, tidur atau belajar di ruangan yang sama, atau menghabiskan waktu di dalam ruangan dengan seseorang dengan TB positif (CDC, 2016). Menurut Rahajoe (2008) anak dengan usia kurang dari 1 tahun merupakan bagian dari kelompok umur yang rentan terhadap masalah kesehatan gizi. Kerentanan anak usia kurang dari 1 tahun berkaitan dengan sistem imunitas yang belum terbentuk dengan baik. Dengan berdasar pada hal tersebut maka dalam penelitian ini peneliti memfokuskan pada anak usia 1-14 tahun, selain itu 
juga berdasarkan data dari Balkesmas Pati tahun 2016-Februari 2017, 93\% kasus TB pada anak terjadi pada usia 1-14 tahun, sedangkan untuk usia 0-1 tahun hanya 7\% dari seluruh jumlah penderita TB anak. Penularan penyakit TB sangat cepat karena ditularkan melalui udara (droplet nuclei) saat pasien TB batuk dan dari percikan ludah yang mengandung bakteri tersebut terhirup oleh anak sehingga akan terhisap ke dalam paru anak yang sehat [5]

Dari studi pendahuluan yang telah dilakukan dengan wawancara langsung pada tanggal 15 Maret 2017 di Balai Kesehatan Masyarakat (Balkesmas) Pati terdapat 3 pasien anak penderita TB yang berusia 3 tahun, 8 tahun dan 11 tahun. Dari hasil wawancara dengan orang tua pasien ternyata 2 responden menyatakan bahwa anak pernah tinggal dengan penderita TB paru positif. Sedangkan 1 responden menyatakan bahwa tidak pernah tinggal serumah dengan penderita TB, tetapi pernah kontak dengan tetangga/pengasuh yang memiliki riwayat TB paru positif. Dengan berdasarkan pada uraian diatas maka peneliti akan melakukan penelitian tentang hubungan riwayat kontak penderita dengan kejadian Tuberkulosis Paru anak usia 1-14 tahun di Balkesmas Pati.

\section{METODE PENELITIAN}

Desain penelitian ini menggunakan penelitian analitik observasional dengan pendekatan case control. Penelitian ini dilakukan di klinik TB Balai Kesehatan Masyarakat (Balkesmas) Pati. Populasi dalam penelitian ini adalah anak usia 1-14 tahun yang positif TB dan diobati di Balkesmas Pati dengan jumlah sampel sebanyak 26 responden kelompok kasus dan 26 responden kelompok kontrol. Jenis instrumen yang dipilih oleh peneliti adalah menggunakan kuesioner yang telah diuji validitas dan reliabilitas. Analisis data menggunakan analisa univariat dan bivariat dengan uji chisquare menggunakan program komputer SPSS 16.0 for window. 


\section{HASIL DAN PEMBAHASAN}

\section{Kejadian TB Paru Anak}

Tuberkulosis pada anak merupakan masalah khusus yang berbeda dengan tuberkulosis pada orang dewasa. Terjadinya tuberkulosis (TB) pada anak juga disebabkan oleh bakteri Mycobacterium tuberculosis. TB menyebar dari orang ke orang melalui udara. Ketika orang-orang dengan batuk TB paru, bersin atau meludah, mereka mendorong kuman TB ke udara. Orang yang terapapar bakteri tersebut akan mengalami infeksi primer. Infeksi dimulai saat kuman tuberkulosis berhasil berkembang biak dengan cara pembelahan diri di paru, yang mengakibatkan peradangan di dalam paru. Terjadinya tuberkulosis pada anak bisa disebabkan karena adanya kontak riwayat, kondisi rumah, kepadatan penghuni rumah, status ekonomi keluarga, imunisasi BCG, dan status gizi. Tapi dalam penelitian ini peneliti mendalami akan penyebab tuberkulosis jika dilihat dari ada tidaknya riwayat kontak dengan penderita TB sebelumnya.

Tabel 1

Distribusi Frekuensi kejadian TB Paru anak usia 1-14 tahun

\begin{tabular}{ccccc}
\hline \multirow{2}{*}{ TB Paru Anak } & \multicolumn{2}{c}{ Kontrol } & \multicolumn{2}{c}{ Kasus } \\
\cline { 2 - 5 } & $\mathbf{f}$ & $\%$ & $\mathbf{f}$ & $\%$ \\
\hline TB (BTA +) & 0 & 0 & 26 & 100 \\
Tidak TB (BTA -) & 26 & 100 & 0 & 0 \\
\hline Total & 26 & 100 & 26 & 100 \\
\hline
\end{tabular}

Pada tabel 1 menunjukkan bahwa dari 52 responden yang terdiri dari 26 responden kasus dan 26 responden kontrol, pada kelompok kasus didapatkan hasil bahwa 26 responden positif TB (100\%) sedangkan pada kelompok kontrol 26 responden menunjukkan hasil negatif (100\%). Hal ini berdasarkan data sekunder dengan melihat rekam medis pasien hasil pemeriksaan radiologi dan tuberculin yang ada di Balkesmas Pati. Sedangkan untuk responden kontrol ada 26 anak yang negatif TB tapi memiliki riwayat kontak dengan penderita TB positif. 


\section{Riwayat Kontak}

Riwayat kontak merupakan salah satu indikator penting dalam proses diagnosis tuberkulosis anak. Kontak itu sendiri bisa dari beberapa sumber, seperti keluarga (serumah), di sekolah dan dari tetangga/pengasuh anak. Dalam mendalami ada tidaknya riwayat kontak pada instrumen penelitian yang digunakan peneliti yang ditekankan adalah 3 aspek tersebut. Dengan berdasar hal tersebut kita bisa mengetahui terjadinya tuberkulosis pada anak tersebut disebabkan karena adanya kontak dengan serumah, di sekolah atau dari tetangga/pengasuh anak. Jika telah diketahui faktor utama penyebabnya maka kita akan bisa lebih waspada dan mencegah untuk tidak terjadinya kontak apabila ditemukan penderita TB di lingkungan yang dianggap rawan menularkan.

\section{Tabel 2}

Distribusi Frekuensi riwayat kontak penderita terhadap kejadian TB anak usia 1-14 tahun

\begin{tabular}{lcccc}
\hline \multirow{2}{*}{ Riwayat Kontak } & \multicolumn{2}{c}{ Kontrol } & \multicolumn{2}{c}{ Kasus } \\
\cline { 2 - 5 } & F & $\%$ & $\mathbf{f}$ & $\%$ \\
\hline Kontak serumah & 8 & 30,8 & 11 & 42,4 \\
Kontak di sekolah & 7 & 26,9 & 3 & 11,5 \\
Kontak tetangga & 1 & 3,8 & 9 & 34,6 \\
Tidak kontak & 10 & 38,5 & 3 & 11,5 \\
\hline \multicolumn{1}{c}{ Total } & 26 & 100 & 26 & 100 \\
\hline
\end{tabular}

Pada tabel 2 menunjukkan bahwa pada kelompok kontrol yang terbanyak ternyata adanya kontak keluarga yang telah positif TB (serumah) ada $8(30,8 \%)$ dan yang tidak ada riwayat kontak ada 10 $(38,5 \%)$. Sedangkan pada kelompok kasus menunjukkan bahwa yang terbanyak adalah karena adanya kontak dengan penderita TB yang tinggal serumah yaitu ada 11 (42,4\%) dan yang tidak adanya kontak 3 (11,5\%). Yang berarti dapat disimpulkan bahwa penyakit TB paru pada anak apabila sebelumnya telah memiliki riwayat kontak dengan penderita TB paru positif akan lebih beresiko untuk tertular dan hampir 50\% dalam 
keluarga sudah ada yang menderita TB paru positif sebelumnya sehingga TB pada anak yang diobati di Balkesmas Pati disebabkan karena adanya kontak dengan penderita TB yang tinggal serumah.

\section{Hubungan Riwayat Kontak dengan Kejadian Tuberkulosis Paru Anak}

Pada tabel 1.3 didapatkan nilai $r$ tabel 12,243 artinya $r$ hitung $>r$ tabel $(7,81)$ yang dapat disimpulkan bahwa Ha diterima Ho ditolak yang berarti hubungan antara riwayat kontak dan TB pada anak signifikan. Jika dilihat dari hasil uji statistik memperlihatkan nilai $p$ value $<0,05(p=0,007)$ yang berarti terdapat hubungan yang bermakna antara riwayat kontak penderita dengan kejadian tuberkulosis paru anak usia 1-14 tahun di Balkesmas Pati. Dengan hasil tersebut memperlihatkan bahwa jika kita kontak dengan penderita TB positif dalam waktu yang intensif akan mengakitkan bakteri Mycobacterium tuberculosis masuk dalam tubuh seseorang dengan cepat. Anak yang daya tahan tubuhnya masih lemah akan semakin mudah untuk tertular, yang bisa dilihat dari hasil penelitian dari 26 responden kelompok kasus 23 responden menyatakan bahwa sebelumnya pernah kontak dengan penderita TB paru baik yang bersumber dari keluarga serumah, sekolah ataupun dari tetangga/pengasuh anak.

Tabel 3

Uji Hubungan Riwayat Kontak Penderita dengan Kejadian TB Anak

\begin{tabular}{|c|c|c|c|c|c|c|c|c|c|}
\hline \multirow{3}{*}{$\begin{array}{l}\text { Riwayat } \\
\text { Kontak }\end{array}$} & \multicolumn{4}{|c|}{ Kejadian TB paru anak } & & & \multirow{3}{*}{$\begin{array}{c}P \\
\text { value }\end{array}$} & \multirow{3}{*}{$\begin{array}{c}r \\
\text { hitung }\end{array}$} & \multirow{3}{*}{$\begin{array}{c}r \\
\text { (korelasi) }\end{array}$} \\
\hline & \multicolumn{2}{|c|}{$\begin{array}{c}\text { Kontrol (tidak } \\
\text { TB) }\end{array}$} & \multicolumn{2}{|c|}{$\begin{array}{l}\text { Kasus } \\
\text { (TB) }\end{array}$} & \multicolumn{2}{|c|}{ Total } & & & \\
\hline & $\mathbf{N}$ & $\%$ & $\mathbf{N}$ & $\%$ & $\mathbf{N}$ & $\%$ & & & \\
\hline $\begin{array}{l}\text { Kontak } \\
\text { serumah }\end{array}$ & 8 & 30,8 & 11 & 42,4 & 19 & 36,6 & & & \\
\hline $\begin{array}{l}\text { Kontak di } \\
\text { sekolah }\end{array}$ & 7 & 26,9 & 3 & 11,5 & 10 & 19,2 & & & \\
\hline $\begin{array}{l}\text { Kontak } \\
\text { tetangga }\end{array}$ & 1 & 3,8 & 9 & 34,6 & 10 & 19,2 & 0,007 & 12,243 & 0,437 \\
\hline Tidak kontak & 10 & 38,5 & 3 & 11,5 & 13 & 25 & & & \\
\hline Total & 26 & 100 & 26 & 100 & 52 & 100 & & & \\
\hline
\end{tabular}


Hasil penelitian ini sejalan dengan penelitian yang yang telah dilakukan oleh Yulistyaningrum dan Dwi Sarwani Sri Rejeki tentang Hubungan Riwayat Kontak Penderita Tuberkulosis Paru (TB) dengan Kejadian TB Paru Anak di Balai Pengobatan Penyakit Paru-Paru (BP4) Purwokerto, dari hasil penelitian tersebut ditemukan bahwa riwayat kontak memiliki hubungan yang signifikan terhadap penyakit TB. Dapat dilihat dari Odds Ratio sebesar 6,378 artinya yaitu adanya riwayat kontak dengan penderita TB paru positif mempunyai resiko tertular TB Paru sebesar 6,378 kali lebih banyak dari orang yang tidak memiliki riwayat kontak dan nilai $p$ sebesar 0,001 . Sedangkan penelitian yang telah dilakukan peneliti di Balkesmas Pati menunjukkan bahwa nilai $p$ value sebesar 0,007 ; seperti yang telah dijelaskan sebelumnya. Jika dibandingkan dengan penelitian yang dilakukan oleh Yulistyaningrum dan Dwi Sarwani Sri Rejeki nilai OR (faktor resiko) dari hasil penelitian ini kemungkinan paparan faktor resikonya lebih rendah dan untuk $p$ value penelitian ini juga lebih besar sehingga hubungan antara 2 variabel tidak kuat [10]

Tapi jika dibandingkan dengan penelitian yang telah dilakukan oleh Dwi Purnomo Sidhi, penelitian ini lebih memiliki hubungan yang lebih kuat dibandingkan penelitian sebelumnya yang artinya adanya riwayat kontak lebih berpengaruh terhadap terjadinya TB paru pada anak. Hal ini bisa dilihat dari nilai $p$ value sebesar 0,047 sedangkan nilai OR 3,90 yang artinya resiko tertularnya hanya 3,90 kali lebih beresiko anak akan menderita TB paru dibandingkan dengan responden yang tidak memiliki riwayat kontak sebelumnya. Sedangkan penelitian ini didapatkan hasil nilai $p$ value sebesar 0,007 . Dari hasil tersebut dapat terlihat bahwa terjadinya TB pada anak di Balkesmas Pati penyebab utamanya karena adanya kontak dengan penderita TB sebelumnya.

Dari penelitian diatas dapat dilihat kesamaan bahwa riwayat kontak mempunyai hubungan yang bermakna dengan kejadian TB Paru pada anak. Riwayat kontak adalah awal proses transmisi untuk infeksi penyakit TB masuk dalam tubuh anak. Berarti ini merupakan faktor resiko untuk 
timbulya TB Paru karena responden memiliki riwayat kontak dengan penderita TB paru positif, yang tanpa mereka sadari bakteri Mycobacterium tuberculosis telah berkembang dalam tubuh mereka [4].

\section{SIMPULAN DAN SARAN}

\section{Simpulan}

Simpulan dari penelitian ini diketahui bahwa pada kelompok kontrol yang memiliki riwayat kontak serumah ada $8(30,8 \%)$, kontak di sekolah ada $7(26,9 \%)$, kontak dengan tetangga $1(3,8 \%)$ dan yang tidak memiliki riwayat kontak 10 anak (38,5\%). Sedangkan pada kelompok kasus yang memiliki riwayat kontak serumah ada 11 anak (42,4\%), kontak di sekolah $3(11,5 \%)$, kontak dengan tetangga $9(34,6 \%)$ dan yang tidak memiliki riwayat kontak 3 anak (11,5\%). Sedangkan dari hasil analisis bivariat disimpulkan bahwa ada hubungan yang bermakna antara riwayat kontak penderita dengan kejadian TB paru anak usia 1-14 tahun di Balkesmas Pati $(p$ value $=0,007$, $r$ hitung $=12,243$ dan $r($ korelasi $)=0,437)$.

\section{Saran}

Saran pada penelitian ini adalah orang tua khususnya ibu diharapkan dapat menambah pengetahuan tentang pencegahan TB paru, misalnya melalui media elektronik maupun media cetak. Untuk mencegah terjadinya penyakit TB paru pada anak diharapkan agar petugas lebih meningkatkan kualitas dan kuantitas kegiatan Program Pemberantasan Penyakit TB Paru (P2TB Paru). Sehingga akan memberikan informasi kepada peneliti lain untuk dapat dipergunakan sebagai referensi pada penelitian lanjutan.

\section{DAFTAR PUSTAKA}

[1] CDC. (2016). Improved Detection of Tuberculosis and MultidrugResistant Tuberculosis among Tibetan Refugees, India. Jenewa: World Health Organization.

[2] Data Tahunan Balkesmas Pati. (2016). Rekap Data Tahunan 2016, Balai Kesehatan Masyarakat Pati, Pati. 
[3] Dinas Kesehatan Kabupaten Pati (2016). Profil Kesehatan Kabupaten Pati Tahun 2016, Dinas Kesehatan Kabupaten Pati, Pati.

[4] Luh, D.L., You, Z.S. \& Chen, S.C. (2016). 'Comparison of the social contact patterns among school-age children in specific seasons, locations, and times', Epidemics, vol. 14 (2016), p. 36-44.

[5] Rahajoe, (2008). Pedoman Nasional Tuberkulosis Anak. Cetakan Kedua dengan revisi. UKK Respirologi PP IDAI, Jakarta.

[6] Sastroasmoro, S. (2011). Dasar-Dasar Metodologi Penelitian Klinis,ed. 4. Sagung Seto: Jakarta.

[7] Sidhi, D.P. (2010). Riwayat Kontak Tuberkulosis Sebagai Faktor Resiko Hasil Tuberkulin Positif. Tesis. Universitas Diponegoro, Semarang.

[8] WHO. (2016). Tuberculosis. Jenewa: World Health Organization.

[9] Widoyono. (2011). Penyakit Tropis, ed. 2. Penerbit Erlangga: Semarang.

[10] Yulistyaningrum \& Rejeki, D.S.S. (2010). 'Hubungan Riwayat Kontak Penderita Tuberkulosis Paru (TB) dengan Kejadian TB Paru Anak di Balai Pengobatan Penyakit Paru-Paru (BP4) Purwokerto', Jurnal Kesmas UAD, vol. 4 No. 1, September 2010, p.43-48. 


\section{PEDOMAN PENULISAN NASKAH JKM}

Jurnal Kesehatan Masyarakat (JKM) STIKES Cendekia Utama Kudus menerima naskah hasil-hasil riset, artikel ilmiah, studi/ analisa kritis, skripsi, tesis, disertasi dan tulisan ilmiah lain di bidang kesehatan masyarakat.

Naskah adalah karya asli penulis/ peneliti, bukan plagiat, saduran atau terjemahan karya penulis/ peneliti lain. Naskah khusus ditujukan kepada Jurnal Kesehatan Masyarakat (JKM) STIKES Cendekia Utama Kudus, belum pernah dipublikasikan di media lain.

Naskah yang dikirim harus disertai surat persetujuan publikasi dan surat pengantar yang ditandatangani peneliti/ penulis.

Komponen naskah:

- Judul, ditulis maksimal 150 karakter, huruf Book Antiqua, ukuran 13, spasi 1

- Identitas penulis, ditulis setelah judul. Terdiri atas nama (tanpa gelar), alamat tempat kerja, nomor telepon/hp dan alamat email.

- Abstrak dalam bahasa Indonesia dan bahasa Inggris, maksimal 200 kata, disusun dalam satu alinea, berisi masalah, tujuan, metode, hasil dan 3-5 kata kunci. Untuk naskah dalam bahasa Inggris, tidak perlu disertai abstrak dalam bahasa Indonesia.

- Pendahuluan, tanpa subjudul, berisi latar belakang, sedikit tinjauan pustaka dan tujuan penelitian.

- Metode penelitian, dijelaskan secara rinci, disain, populasi, sampel, sumber data, teknik/ instrumen pengumpul data, dan prosedur analisis data.

- Hasil dan Pembahasan, mengurai secara tepat dan argumentatif hasil penelitian, kaitan hasil dengan teori yang sesuai dan sistematis.

- Tabel atau gambar. Tabel, diberi nomor sesuai urutan penyebutan dalam teks, ditulis 1 (satu) spasi, ukuran 11. Judul singkat, padat dan jelas, terletak di atas tabel. Gambar, diberi nomor sesuai urutan penyebutan dalam teks. Judul singkat, padat dan jelas, terletak di bawah gambar.

- Simpulan dan Saran. Simpulan menjawab masalah penelitian, pernyataan tegas. Saran logis, tepat guna dan tidak mengada-ada, dan ada keterkaitan dengan keberlanjutan penelitian

- Rujukan/ referensi ditulis sesuai aturan Vancouver, urut sesuai dengan pemunculan dalam keseluruhan teks, maksimal 25 rujukan dan 75 persen merupakan publikasi dalam 10 tahun terakhir. 
Naskah sebanyak 15-25 halaman kuarto, batas atas-bawah-tepi kiri-tepi kanan (cm) : 4-3-4-3, spasi 1,5, jenis huruf: arial, ukuran 12, format Microsoft word, dalam bentuk softfle dan 3 (tiga) eksemplar dalam bentuk print out.

Naskah dikirim ke alamat : Redaksi Jurnal Kesehatan Masyarakat (JKM) STIKES Cendekia Utama Kudus, Jl. Lingkar Raya Km.05 Jepang Mejobo Kudus 59381.

Kontak langsung dapat melalui:

- Eko Prasetyo : 081228475759 / 081575435102

- Sri Wahyuningsih : 085740572288

Naskah juga dapat dikirim melalui email : jkm.cendekiautama@gmail.com

\section{Contoh penulisan daftar pustaka :}

\section{Artikel Jurnal Penulis Individu}

Sloan NL, Winikoff B, Fikree FF. An ecologic analysis of maternal mortality ratios. Stud Fam Plann 2001;32:352-355.

\section{Artikel Jurnal Penulis Organisasi}

Diabetes Prevention Program Research Group. Hypertension, insulin, and proinsulin in participants with impaired glucose tolerance. Hypertension.2002;40(5):679-86

\section{Artikel Jurnal di Internet}

Goodyear-Smith F and Arroll B, Contraception before and after termination of pregnancy: can we do it better? New Zealand Medical Journal, 2003, Vol. 116, No. 1186, <http://www.nzma.org.nz/journal/1161186/683/content. pdf>, accessed Aug. 7, 2007.

\section{Buku Dengan Nama Editor sebagai penulisnya}

Lewis G, ed. Why mothers die 2000-2002: the confdential enquiries into maternal deaths in the United Kingdom. London: RCOG Press; 2004.

\section{Buku yang Ditulis Individu}

Loudon I. Death in childbirth. An international study of maternal care and maternal mortality 1800-1950.London: Oxford University Press, 1992.50

\section{Buku yang Ditulis Organisasi}

Council of Europe, Recent Demographic Developments in Europe 2004,Strasbourg, France: Council of Europe Publishing, 2005. 


\section{Artikel dari Buletin}

Ali MM, Cleland $\mathrm{J}$ and Shah $\mathrm{IH}$, Condom use within marriage: a neglected HIV intervention, Bulletin of the World Health Organization, 2004, 82(3):180-186.

\section{Paper yang Dipresentasikan dalam Pertemuan IImiah/Konferensi}

Kaufman J, Erli Z and Zhenming X, Quality of care in China: from pilot project to national program, paper presented at the IUSSP XXV International Population Conference, Tours, France, July 18-23, 2005.

\section{BAB dalam Buku}

Singh S, Henshaw SK and Berentsen K, Abortion: a worldwide overview, in: Basu AM, ed., The Sociocultural and Political Aspects of Abortion,Westport, CT, USA: Praeger Publishers, 2003, pp. 15-47.

\section{Data dari Internet}

U.S. Bureau of the Census, International Data Base, Country summary: China, 2007, <http://www.census.gov/ipc/www/idb/country/chportal.html>, accessed Aug. 12, 2007.

\section{Disertasi}

Lamsudin R. Algoritma Stroke Gadjah Mada (Disertasi). Yogyakarta: Universitas Gadjah Mada. 1997

\section{Makalah dalam Surat Kabar}

Banzai VK, Beto JA. Treatment of Lupus Nephritis. The Jakarta Post 1989; Dec 8; Sect A.5(col 3)

\section{Kamus}

Ectasia. Dorland's Illustrated Medical Dictionary.27th ed. Philadelphia: Saunders, $1988 ; 527$ 


\title{
UCAPAN TERIMA KASIH DAN PENGHARGAAN
}

\author{
Kepada Yang Terhormat : \\ Sigit Ari Saputro, S.KM., M.Kes. \\ Universitas Airlangga, Surabaya, Indonesia \\ dr. Mahalul Azam, M.Kes. \\ Universitas Negeri Semarang, Indonesia \\ Eti Rimawati, S.KM., M.Kes. \\ Universitas Dian Nuswantoro, Semarang, Indonesia \\ Didik Sumanto, S.KM., M.Kes. (Epid) \\ Universitas Muhammadiyah Semarang, Indonesia \\ Selaku reviewer (Mitra Bestari) dari \\ Jurnal Kesehatan Masyarakat (JKM) Cendekia Utama \\ STIKES Cendekia Utama Kudus
}

